\title{
SYMPOSIUM ON INDUSTRY ASSOCIATIONS IN TRANSNATIONAL LEGAL ORDERING
}

\section{THE RISE OF SECTORALLY DIFFERENTIATED CONTRACT LAW}

\author{
Joshua Karton*
}

This essay identifies an underappreciated side-effect of the increasing influence of industry associations in the development of transnational law. As the law governing commercial contracts harmonizes across territorial boundaries, it will increasingly split along boundaries between industry sectors, a phenomenon I call "sectoral differentiation." Sectoral differentiation is largely a by-product of the growth of transnational legal orders in an environment where state laws and networks may be unable to keep pace with commercial globalization. Industry associations are not the sole drivers of sectoral differentiation, but their activities often promote it, either directly through rulemaking activities related to their particular industries, or indirectly through influence on treaty drafting and other national and international rulemaking processes.

\section{What is Sectoral Differentiation?}

In the transnational commercial law community, globalization is often seen as an unmitigated boon, and the story of transnational law is told as an epic of ever-increasing harmonization and unification, mostly as a by-product of the drive for greater efficiencies in international commerce. ${ }^{1}$ Much of the literature on transnational commercial law indulges in a technocratic utopianism, hailing the dawn of a new era of globally-harmonized contract law that evolves at the speed of business. ${ }^{2}$

The globalization boosters mistakenly equate globalization with unification. In fact, the phenomenon of "convergence" coupled with "informed divergence" is a hallmark of many areas of globalization. ${ }^{3}$ But beyond this, globalization is not a unitary process; it occurs in different ways at different speeds in different aspects of society. The typical picture of transnational contract law as harmonized or unified is therefore not incorrect per se, but it is incomplete. Even as contract law globalizes, it is splitting along industry lines, so that disputes arising in different industry sectors are decided according to industry-specific rather than generally-applicable rules.

* Associate Professor and Associate Dean for Graduate Studies and Research, Queen's University Faculty of Law.

${ }^{1}$ See, e.g., Bryan H. Druzin, Anarchy, Order, and Trade: A Structuralist Account of Why a Global Commercial Order is Emerging, 47 VAnd. J. Transnat'L L. 1049, 1053 (2014) (arguing that "The basic structure of trade drives toward convergence- a fact that may be discerned as much on the macrolevel of state actors as it is on the microlevel of private parties."). Druzin acknowledges that market-induced uniformity is not perfect and is often overstated. $\underline{I d}$. at 1076.

${ }^{2}$ Cf. Ralf Michaels, Dreaming law without a state: scholarship on autonomous international arbitration as utopian literature, 1 LONDON REv. INT'L L. 35 (2013).

3 These terms were coined and elucidated by Anne-Marie Slaughter; see Anne-Marie Slaughter, A New World Order (2004).

\footnotetext{
The American Society of International Law and Joshua Karton (C 2017. This is an Open Access article, distributed under the terms of the Creative Commons Attribution licence (http://creativecommons.org/licenses/by/4.0/), which permits unrestricted re-use, distribution, and reproduction in any medium, provided the original work is properly cited.
} 
Sectoral differentiation contrasts with the two ways that contract law has historically been subdivided: territorially and functionally. ${ }^{4}$ Territorial differentiation means simply that different bodies of law apply in different states. The growth of transnational law has diminished the extent of territorial differentiation in contract law, but it is still largely accurate to say that each state develops and enforces its own contract law, and that the applicable rules are mostly determinable by identification under conflict-of-laws rules of the state whose law governs the transaction.

In addition to territorial differentiation, contract law has traditionally been subdivided functionally, meaning that different bodies of rules apply to different types of transactions. For example, the American Uniform Commercial Code is divided into articles dealing with sales, leases, letters of credit, and so on. In civil law jurisdictions, civil codes and codes of commerce or obligations have a similar structure. Most uniform law treaties and model laws deal with one functional type of transaction, such as the UN Conventions on Contracts for the International Sale of Goods and on Independent Guarantees and Stand-by Letters of Credit.

The sectoral differentiation described in this essay is new. It means, for example, that a sale of crude oil from a producer to a refiner and a sale of office paper from a manufacturer to the same refiner are governed by distinct bodies of rules because one sale involves oil and the other involves stationery, even though both constitute sales of goods between commercial entities. Traditional distinctions between functionally distinct transactions will matter less, as will the nationalities of the contracting parties and the place of the contract's performance. In contrast, the boundaries between industry sectors will matter more. In other words, what type of contract is implicated in a dispute will gradually become less significant in determining the applicable rules, while the subject matter of the contract will become more significant.

Merchants in different industries inevitably develop their own conventions and standard terms. To the extent governance is shaped by contract, it has always varied across sectors. By contrast, courts have traditionally analyzed all private agreements under the broad rubric of "contract law." Today, however, public lawmaking may simply validate, incorporate, or supplement rules or standards that originate from private rulemaking, such as the codifications promulgated by industry associations. ${ }^{5}$ The sectorally differentiated structure of the commercial community is increasingly reflected in formal contract law. Contracts are said to be negotiated in the shadow of the law; now, law is being remade in the shadow of contract.

\section{How does Sectoral Differentiation Happen?}

Sectoral differentiation occurs whenever rulemaking entities (whether private or public, national or international, formal or informal, regulatory or legislative or adjudicative) adopt legal rules that yield different outcomes for similar transactions occurring in different industry sectors. I call such rules "industry-particularist," while "generalist" rules apply broadly to one or more categories of transactions across all areas of commerce. Industry-particularism is the micro-level expression of the macro-level phenomenon of sectoral differentiation.

The rise of sectoral differentiation is not the result of coordinated or deliberate action by industry associations or any other group, but rather the by-product of organic processes. In our era of globalized business, state networks "cannot provide reliable frameworks of institutional or normative design" to be transposed into the transnational arena, which "opens up a vista on endless confrontations and conflicts between different interest formations,

\footnotetext{
${ }^{4}$ National laws also set distinct rules for categories of relationships deemed worthy of close regulation, either because they relate to important social norms (as in divorce and child custody agreements) or because of the potential for abuse of a dominant position (as in consumer or employment contracts). This essay does not deal with these areas, but only with relationships between commercial parties.

${ }^{5}$ Gregory Shaffer, Theorizing Transnational Legal Ordering, 12 AnN. Rev. L. \& Soc. ScI. 231, 247-248 (2016).
} 
rationalities, and stakes." The key to predicting the evolution of transnational law is, therefore, to identify the networks that will "win" these confrontations by exerting the greatest influence on the generation and content of transnational contract law rules. ${ }^{7}$ These will not necessarily be the largest networks, or the ones with the largest number of powerful or influential members, but rather the networks that are the most cohesive and exhibit the most intensive sustained interactions.

The most influential networks are likely to be those composed of the transnational communities of businesses working in the same industry sector. These networks are further strengthened by industry associations, which provide a forum for harmonizing divergent perspectives within the industry and for overcoming collective action problems that might otherwise prevent business communities from "speaking with one voice," whether to promulgate rules or to influence rule-making processes. To the extent that such industry associations embody transnational legal orders, ${ }^{8}$ their structure will determine the evolving structure of transnational contract law.

Commercial parties prefer industry-particularism, although they may not conceive of the issue in those terms. Industry-particularist rules provide both fairness and efficiency because they yield predictable outcomes. Rules that privilege trade usages and good faith will inevitably be industry-particularist because standard practices vary by industry. Such rules are contextual rather than bright-line, and therefore may appear to be unpredictable or even arbitrary. However, they are predictable to commercial parties because they are rooted in the context within which those parties operate. Moreover, they are likely to be perceived as fair because they yield the outcomes that commercial processes would normally produce if both parties act reasonably and are motivated to cooperate. The applicable governing norms become "normatively settled" in practice.?

Many contract law codification efforts (national and transnational) follow such an "incorporation strategy" with respect to trade usages. ${ }^{10}$ To the extent that usages are employed to fill gaps and interpret ambiguities in contracts, their function is to hold contracting parties to their own presumed intentions; however, when business practice becomes a source of freestanding rules, the effect is sectoral differentiation. It occurs through at least three distinct mechanisms, described below.

\section{Promulgation of industry-particularist rules}

The most straightforward source of sectorally differentiated contract law is the direct promulgation of bodies of rules that apply to a specific industry. These rules can take a variety of forms but, except for the gradual adoption of sectorally differentiated rules through case law, they all involve some kind of codification of industry practices. The most successful codifications, in terms of uptake by commercial parties, have been undertaken by or with the extensive input of industry associations. Unsurprisingly, they differ based on the industry involved and its particular circumstances. In this way, the transnational rulemaking process tends toward sectoral differentiation. Here are the most common types of sectorally differentiated bodies of rules.

- Standard form contracts that constitute a form of legal governance by virtue of their comprehensive terms and widespread adoption by participants in a globalized industry sector, regardless of their

\footnotetext{
${ }^{6}$ Peer Zumbansen, Transnational Private Regulatory Governance: Ambiguities of Public Authority and Private Power, 76 L. \& CONTEMP. PROBs. 117 , 131 (2013).

${ }^{7}$ I use the term "networks" in a broad and nontechnical way. Many such networks give rise to their own transnational legal orders (according to Shaffer and Halliday's definition). Gregory Shaffer \& Terence C. Halliday, Transnational Legal Orders 4-16 (2015).

${ }^{8} \underline{I d}$.

${ }^{9} \underline{I d}$. at $2-3$.

${ }^{10}$ See, e.g., Jody S. Kraus \& Steven D. Walt, In Defense of the Incorporation Strategy, in JuRisprudential Foundations of CoRporate and Commercial Law 193, 219-20 (Jody S. Kraus \& Steven D. Walt eds., 2000).
} 
nationality. A good example is the set of construction contract forms developed by FIDIC (the International Federation of Consulting Engineers). ${ }^{11}$

- Sets of alternative standardized contract terms from which parties can choose. The best-known example is the "commercial terms"- the three-letter acronyms such as FOB or FCA used in sale of goods contracts, which encode the parties' obligations with respect to delivery of the goods and passage of risk. These were developed largely through the practices of English shipping clerks and the case law of the English courts. However, they are most frequently employed in the codified form of the INCOTERMS published by the International Chamber of Commerce (ICC).

- Self-contained sets of rules, drafted in the style of statutes. Frequently-cited examples include the Uniform Customs and Practice for Documentary Credits (UCP), also promulgated by the ICC, and the Hague-Visby (now Rotterdam) Rules on the carriage of goods by sea, ${ }^{12}$ promulgated by UNCITRAL. References to these instruments (whether in contracts, regulations, or judgments) often use the language of choice of law, such as a term in a letter of credit providing that the instrument is "governed by UCP 600"; however, they are better understood as terms incorporated into a contract by reference, and are enforceable between the parties on that basis.

- Codes of best practices and product standards enacted to help harmonize business operations. These may be incorporated directly into contracts by dominant parties (in individual contracts or throughout a supply chain), but may also be drafted by industry groups and not intended to assume a coercive character. Either way, they are often binding on market participants in practice and, in disputes, may be decisive evidence of trade usages. ${ }^{13}$

- "Common law" principles arising from the decisions of international tribunals on international commercial disputes. These go under various names (such as lex mercatoria and "general principles of commercial law") and their vitality and legitimacy are debated. The most successful exist with respect to specific types of transactions or specific industry sectors, such as the lex petrolea and lex sportiva. These two examples may be overhyped-giving a phenomenon a fancy label may make it seem more important than it actually is. However, a de facto system of precedent now exists in some areas of international contract law, such as with respect to sports.

\section{Industry-wide choice of specific national laws}

A second mechanism by which sectoral differentiation of contract law may arise is the pervasive choice of individual national laws by parties from particular industries, so that different national laws become the de facto global laws of different industries. ${ }^{14}$ This mechanism of sectoral differentiation is an underappreciated aspect of transnational governance, less glamorous and more straightforward than the formal promulgation or informal evolution of transnational law rules. It is largely a consequence of the near-universal enforcement of contractual choice of law clauses in modern private international law. ${ }^{15}$ Such coordinated practice is often facilitated by standard

\footnotetext{
11 See Which FIDIC Contract Should I Use? International Federation of Consulting ENGINEers.

12 Formally, the United Nations Convention on Contracts for the International Carriage of Goods Wholly or Partly by Sea, GA Res. 63/ 122 (Feb. 2, 2009).

13 See Private Standards and Global Governance (Axel Marx et al. eds., 2012).

14 See Erin A. O’Hara \& Larry E. Ribstein, The Law Market (2009).

15 See Peter Nygh, Autonomy in International Contracts 13 (1999) (referring to the "triumph of party autonomy").
} 
forms developed by industry associations. A good example, one with a long history, is the adoption of English law for charter parties and other international shipping contracts; the most popular standard forms in the industry are drafted by the Baltic and International Maritime Council, all of which provide for arbitration in England under English substantive law. ${ }^{16}$

\section{Choice of specialist adjudicative bodies}

The conceptual or normative divisions engendered by sectoral differentiation tend to harden or even grow over time, as specialist adjudicative bodies are established or empowered to apply the differentiated laws. Greater complexity in law leads to demands for greater specialization by adjudicators and counsel. Specialists do not need to be "educated" on the technical specifics, economic context, and legal peculiarities of disputes within their area of specialization. Accordingly, industry and government groups—often working together-have responded to these demands by establishing new specialist courts and arbitral institutions. ${ }^{17}$

Such institutional specialization need not occur along sectoral lines but, in practice, the specialized adjudicative bodies that apply transnational contract law in cross-border business disputes are likely to be industry-specific in the scope of their jurisdiction, or to decide according to industry-particularist rules of law. They may be associated with or established directly under the auspices of industry associations (as are many existing arbitral institutions), by more-loosely-organized industry groups, or even by governments responding to the demand for specialization and seeking to attract legal business to their jurisdictions.

Specialist business tribunals, whether they are judicial or arbitral in character and whether their roots are in the private or public sector, tend over time to adopt the perspectives of the commercial parties who appear in front of them. Only those with relevant commercial law and sector-specific experience (and who therefore have a long history of representing business interests) are likely to be appointed. Once appointed, they are likely to hear only from counsel to these commercial entities. Accordingly, over time their decisions are likely to look more and more like the usages of the industry over which they preside, and less and less like those of generalist courts or of specialist bodies adjudicating disputes involving other industries. ${ }^{18}$

\section{What Are the Broader Implications of Sectoral Differentiation?}

Industry associations inevitably display the sectorally differentiated structure of the commercial communities that establish them. Now, this same structure is being mirrored in positive law. For conceptual clarity and effective application, the law has to be subdivided somehow; otherwise, it would be impossible to define "like cases" so that they could be treated alike. Nevertheless, a shift from a territorially and functionally differentiated contract law to a sectorally differentiated contract law will inevitably produce both winners and losers.

The primary gains from a sectorally differentiated law are accuracy and efficiency, in that legal outcomes are more likely to be aligned with reasonable business outcomes. After all, there is no good reason to think that

\footnotetext{
${ }^{16}$ See BIMCO.

${ }^{17}$ Such as PRIME Finance, whose name was chosen to advertise its arbitrators' industry-specific expertise: "Panel of Recognized International Market Experts in Finance." See About us, P.R.I.M.E. FinANCE. This arbitral institution was established by a group of experienced arbitrators and finance professionals who saw a gap in the market for financial dispute resolution services. It has partnered both with the International Swaps and Derivatives Association, the leading trade association in the sector, and with the Permanent Court of Arbitration and the Dutch government. (PRIME Finance is headquartered in the Netherlands.) $\underline{I d}$.

${ }^{18}$ Douglas H. Ginsburg \& Joshua D. Wright, Antitrust Courts: Specialists vs Generalists, 36 Ford. Int’L L.J. 788, 803-804 (2013) ("replacing a generalist court with a specialized court may entail trading a lower rate of error for a higher degree of bias.”).
} 
one set of rules will be efficient across industries which have different cost structures, risk profiles, and established business norms.

These benefits should not be discounted, but they are also unlikely to be evenly distributed. A shift toward sectorally differentiated law seems to raise technical or sector-specific business information above legal information as the key factor in deciding disputes. This would privilege incumbents over industry newcomers, since incumbents will have had a hand in developing the rules, and newcomers may be bound by rules they have not yet had an opportunity to understand. Where sectoral differentiation is accompanied by a flowering of specialist tribunals, the advantage of incumbents may be entrenched, as they will influence the makeup and jurisprudence of these tribunals through repeat appearances.

Such a shift in the conceptualization of relevant knowledge or expertise away from broad-based legal expertise and toward technical or business expertise may also impair the capacity of states to regulate over time. Even leaving aside issues of regulatory capture, states can rarely compete with the private sector for technical expertise. Industry-specific transnational legal orders are therefore likely to become more influential and autonomous over time. 